\title{
The Current scenario of open access journal initiatives in India
}

Dr. Sarika Sawant

\begin{abstract}
Purpose: The overall aim of the research was to gather the data related to open access journal initiatives in India with respect to its type, funding agency/host organisation, full text availability, article charges etc. Methodology: Various sources of information were consulted such as literature, search engines, directories etc.

Finidings: Results shows that all 178 open access journals were peer reviewed, indexed and abstracted in various indexing and abstracting services, listed with DOAR and O-Jgate.

Limitations: Open access journals which were available on Internet were included but not those which were available on Intranet.

Originality: In the earlier literature it was mentioned only about 100 to 110 open access journals as well as nothing was mentioned about author paid journals. But the present study discovered existence of 178 open access journals with 3 author paid journals
\end{abstract}

Keywords: Open access journals, Open access publishing, open access initiatives

\section{OPEN ACCESS JOURNAL INITIATIVES IN INDIA}

A large number of the journals published from India belong to learned societies and associations, and are published by the association or the editor themselves without the involvement of any commercial publisher. The members of these learned societies receive the print copies of the journals without paying an annual or recurring fee. For continuing their publication activities the associations depend on non-member subscriptions, which are limited in number and restricted by and large to the Indian universities and colleges, on advertisements in print editions, and on income generated from other sources such as the annual conferences of the associations. Most of the Indian journals suffer from 'low circulation - low visibility - low impact factor' syndrome. With many fewer paid regional or international subscriptions, these journals have limited visibility, restricted mainly to the members of the association. With this limited visibility, these journals are cited less frequently than their western counterparts. The low impact 
factor inhibits authors from submitting their quality work to the Indian journals. Thus, it is expected that with OA, Indian journals will be able to reach to a wider audience. At the same time, loss, if any, of paid non-member subscriptions is less likely to have a major effect on the economics of these journals (Sahu \& Parmar, 2006).

\section{OBJECTIVES OF THE PRESENT STUDY}

The overall aim of the research was to gather the data related to open access journal initiatives in India with respect to its type, funding agency/host organisation, full text availability etc.

There were six broad objectives as follows:

$>$ Open access journals and their number

$>$ Subject coverage

$>$ Funding agency or Host organization

$>$ Indexing and abstracting

$>$ Full text availability

$>$ Online/Print format

$>$ Article Charges

\section{METHODOLOGY OF PRESENT STUDY}

The data gathering was done beginning with the process of identification of Open access journals. To identify Open access journals the researcher used various sources of information as follows

1. Literature

2. Search using search engines especially Google

3. Directories of archives/repositories

4. Blogs

5. Wikipaedia

6. Portals

7. Education \& Training institution websites especially Indian institutions 
8. LIS Forum mails and others forums / discussion groups

After identifying the open access journals researcher visited respective web pages and gathered information which was analyzed based on certain parameters such as Type of model, Funding agency or Host organisation, fulltext availability etc are presented in Table No 1. Also researcher contacted a few journal publishers and editors for certain information which was not available from journal websites.

\section{FINDINGS}

\subsection{Number of Open access Journals}

From various sources and through search it was observed that there were 178 Open Access journals available online in India. The data is presented in Table No. 1.

According to the study done by Sahu (2006) India is placed $5^{\text {th }}$ in the list of Open Access (OA) journals, well ahead of countries such as the Netherlands, China, Germany, Australia, and so on, which have higher number of online journals. Among the lowincome countries, India ranks second only to Brazil for the number of OA journals. Almost $50 \%$ of the online journals from India are Open access.

\section{Table No 1: List of Open access journals}

\begin{tabular}{|l|l|l|l|l|}
\hline $\begin{array}{l}\text { Name of Publisher/ Host } \\
\text { Organization }\end{array}$ & No. & $\begin{array}{l}\text { Full text } \\
\text { availabili } \\
\text { ty }\end{array}$ & $\begin{array}{l}\text { Subscriptio } \\
\text { n required } \\
\text { for print } \\
\text { format }\end{array}$ & URL \\
\hline Indian Academy of Sciences & 11 & Varies & Yes & www.ias.ac.in/pubs/journals/ \\
\hline $\begin{array}{l}\text { Indian Medlars center, National } \\
\text { Informatics Centre }\end{array}$ & 40 & Varies & Yes & http://medind.nic.in/ \\
\hline Indian National Science Academy & 3 & 2006 & Yes & http://www.insa.ac.in/ \\
\hline Medknow Publications & 73 & Varies & Yes & http://www.medknow.com \\
\hline Kamla-Raj Enterprises & 7 & Varies & Yes & $\begin{array}{l}\text { http://www.krepublishers.co } \\
\text { m }\end{array}$ \\
\hline $\begin{array}{l}\text { Anil Aggrawal's Internet Journal of } \\
\text { Forensic Medicine and Toxicology/ Anil } \\
\text { Aggrawal }\end{array}$ & 1 & 2000 & $\begin{array}{l}\text { No print } \\
\text { version but } \\
\text { for CD }\end{array}$ & $\begin{array}{l}\text { http://www.geradts.com/ } \\
\text { anil/ij/indexpapers.html }\end{array}$ \\
\hline $\begin{array}{l}\text { Calicut Medical Journal / CMC Alumni } \\
\text { Association }\end{array}$ & 1 & 2003 & No print & $\begin{array}{l}\text { http://www.calicutmedicaljou } \\
\text { rnal.org/ }\end{array}$ \\
\hline $\begin{array}{l}\text { Carbon -Science and Technology/ } \\
\text { Applied Science Innovations P Ltd }\end{array}$ & 1 & 2008 & No print & $\begin{array}{l}\text { http://www.applied-science- } \\
\text { innovations.com/indexpagej. }\end{array}$ \\
\hline
\end{tabular}




\begin{tabular}{|c|c|c|c|c|}
\hline & & & & htm \\
\hline $\begin{array}{l}\text { Conservation and Society/ Ashoka Trust } \\
\text { for Research in Ecology and the } \\
\text { Environment' (ATREE), Bangalore }\end{array}$ & 1 & 2003 & Yes & $\begin{array}{l}\text { http://www.conservationand } \\
\text { society.org/ }\end{array}$ \\
\hline $\begin{array}{l}\text { Contemporary Issues and Ideas in Social } \\
\text { Sciences/ Society for Research in Social } \\
\text { Sciences }\end{array}$ & 1 & 2005 & No print & $\begin{array}{l}\text { http://journal.ciiss.net/ } \\
\text { index.php/ciiss/index }\end{array}$ \\
\hline $\begin{array}{l}\text { DESIDOC } \\
\text { Journal of Library and Information } \\
\text { Technology/ DESIDOC }\end{array}$ & 1 & 2008 & Yes & $\begin{array}{l}\text { http://publications.drdo.gov.i } \\
\text { n/ojs/index.php/djlit/index }\end{array}$ \\
\hline $\begin{array}{l}\text { E-Journal of Chemistry : An } \\
\text { International Quarterly Research Journal } \\
\text { of Chemistry/ WWW Pub-India }\end{array}$ & 1 & 2004 & Yes & $\begin{array}{l}\text { http://www.ejchem.org/index } \\
\text { ed.asp\# }\end{array}$ \\
\hline $\begin{array}{l}\text { ICMR BULLETIN/ Indian Council of } \\
\text { Medical Research }\end{array}$ & 1 & 2000 & Yes & http://icmr.nic.in \\
\hline $\begin{array}{l}\text { Indian Folklife/ National Folklore } \\
\text { Support Centre }\end{array}$ & 1 & 2000 & $\begin{array}{l}\text { Free Print } \\
\text { copy }\end{array}$ & $\begin{array}{l}\text { http://wiki.indianfolklore. } \\
\text { org/index.php?title=Category } \\
\text { :Indian_Folklife }\end{array}$ \\
\hline $\begin{array}{l}\text { Indian Journal of Medical Informatics / } \\
\text { Indian Association for Medical } \\
\text { Informatics }\end{array}$ & 1 & 2007 & Yes & http://ijmi.org \\
\hline $\begin{array}{l}\text { Indian Journal of Neurotrauma/ } \\
\text { Neurotrauma Society of India. }\end{array}$ & 1 & 2004 & Yes & http://www.ijntonline.com/ \\
\hline $\begin{array}{l}\text { Indian Pacing and Electrophysiology } \\
\text { Journal/ Indian Heart Rhythm Society }\end{array}$ & 1 & 2002 & No print & http://www.ipej.org/ \\
\hline $\begin{array}{l}\text { International Journal of Computer } \\
\text { Science and Applications / } \\
\text { Technomathematics Research } \\
\text { Foundation }\end{array}$ & 1 & 2004 & No Print & $\begin{array}{l}\text { http://www.tmrfindia.org/ijcs } \\
\text { a/aim.html }\end{array}$ \\
\hline $\begin{array}{l}\text { International Journal of Cyber } \\
\text { Criminology / K. Jaishankar }\end{array}$ & 1 & 2007 & No Print & $\begin{array}{l}\text { http://www.cybercrimejourna } \\
\text { l.co.nr/ }\end{array}$ \\
\hline $\begin{array}{l}\text { International Journal of Integrative } \\
\text { Biology/Omics Group }\end{array}$ & 1 & 2007 & No print & $\begin{array}{l}\text { http://www.classicrus.com/IJ } \\
\text { IB/ }\end{array}$ \\
\hline Internet Health/VirtualMed & 1 & 2003 & No print & $\begin{array}{l}\text { http://www.internet- } \\
\text { health.org/ }\end{array}$ \\
\hline $\begin{array}{l}\text { Journal of Association of Physicians of } \\
\text { India /Association of Physicians of India }\end{array}$ & 1 & 2000 & $\begin{array}{l}\text { Print and } \\
\text { CD }\end{array}$ & $\begin{array}{l}\text { http://www.japi.org/index.ht } \\
\text { ml }\end{array}$ \\
\hline $\begin{array}{l}\text { Jkscience: Journal of Medical education } \\
\text { and research/ Dr. Annil Mahaja }\end{array}$ & 1 & 2004 & Yes & http://www.jkscience.org/ \\
\hline $\begin{array}{l}\text { Journal of Neonatology/ The National } \\
\text { Neonatology Forum (NNF) }\end{array}$ & 1 & 2003 & Yes & http://www.jnnfi.org/ \\
\hline $\begin{array}{l}\text { Journal of Orthopaedics/Calicut } \\
\text { Medical College }\end{array}$ & 1 & 2004 & No print & http://www.jortho.org/ \\
\hline $\begin{array}{l}\text { Journal of Semi-Arid Tropical } \\
\text { Agricultural Research /ICRISAT }\end{array}$ & 1 & 2005 & No Print & $\begin{array}{l}\text { http://ejournal.icrisat.org/ } \\
\text { archives.htm }\end{array}$ \\
\hline $\begin{array}{l}\text { Journal of the Indian Academy of } \\
\text { Geriatrics /Indian Academy of Geriatrics }\end{array}$ & 1 & 2005 & Yes & $\begin{array}{l}\text { http://www.jiag.org/index.ht } \\
\text { ml }\end{array}$ \\
\hline $\begin{array}{l}\text { Journal of Tropical Agriculture/Kerala } \\
\text { Agricultural university }\end{array}$ & 1 & 2001 & Yes & $\begin{array}{l}\text { http://www.jtropag.in/index.p } \\
\text { hp/ojs/about }\end{array}$ \\
\hline $\begin{array}{l}\text { KnowGenesis : International Journal for } \\
\text { Technical Communication } \\
\text { /KnowGenesis }\end{array}$ & 1 & 2006 & Yes & $\begin{array}{l}\text { http://www.knowgenesis.com } \\
\text { /journal/index.php?journal=IJ } \\
\text { TC }\end{array}$ \\
\hline $\begin{array}{l}\text { Law, Environment and Development } \\
\text { Journal (LEAD Journal)/ SOAS, IELRC }\end{array}$ & 1 & 2005 & No print & $\begin{array}{l}\text { http://www.lead- } \\
\text { journal.org/index.php }\end{array}$ \\
\hline
\end{tabular}




\begin{tabular}{|c|c|c|c|c|}
\hline $\begin{array}{l}\text { Online Journal of Health \& Allied } \\
\text { Sciences/ B. S. Kakkilaya }\end{array}$ & 1 & 2002 & No Print & $\begin{array}{l}\text { http://www.ojhas.org/index.h } \\
\text { tm }\end{array}$ \\
\hline $\begin{array}{l}\text { Pharmacognosy Magazine / Phcog.Net, } \\
\text { Al-Ameen College of Pharmacy, } \\
\text { Bangalore }\end{array}$ & 1 & 2005 & Yes & $\begin{array}{l}\text { http://www.phcog.net/ } \\
\text { phcogmag/about.htm }\end{array}$ \\
\hline $\begin{array}{l}\text { Pharmacognosy Reviews } \\
\text { /Pharmacognosy Network Worldwide }\end{array}$ & 1 & 2007 & Yes & $\begin{array}{l}\text { http://www.phcogrev.com/co } \\
\text { ntact.htm }\end{array}$ \\
\hline $\begin{array}{l}\text { PULMON-The Journal of Respiratory } \\
\text { Sciences/ Academy of Pulmonary and } \\
\text { critical care medicine }\end{array}$ & 1 & 1999 & Yes & $\begin{array}{l}\text { http://www.pulmononline.org } \\
/ /\end{array}$ \\
\hline $\begin{array}{l}\text { Sankhya: The Indian Journal of } \\
\text { Statistics/Indian Statistical Institute }\end{array}$ & 1 & 2003 & Yes & $\begin{array}{l}\text { http://sankhya.isical.ac.in/ind } \\
\text { ex.html }\end{array}$ \\
\hline $\begin{array}{l}\text { Solapur Medical Journal/Dr. V. M. } \\
\text { Govt. Medical College }\end{array}$ & 1 & 2004 & Yes & http://vaishampayan.org/smj/ \\
\hline $\begin{array}{l}\text { The International Journal of Criminal } \\
\text { Justice Sciences (IJCJS) / K. Jaishankar }\end{array}$ & 1 & 2006 & No Print & http://www.ijcjs.co.nr/ \\
\hline $\begin{array}{l}\text { Bombay Hospital Journal/ Bombay } \\
\text { Hospital Institute of Medical Sciences }\end{array}$ & 1 & 1996 & Yes & $\begin{array}{l}\text { http://www.bhj.org/index.ht } \\
\text { m }\end{array}$ \\
\hline $\begin{array}{l}\text { Journal of the Indian Medical } \\
\text { Association/ Indian Medical } \\
\text { Association, }\end{array}$ & 1 & 2007 & Yes & $\begin{array}{l}\text { http://www.jimaonline.org.in } \\
\text { /jimastart.html }\end{array}$ \\
\hline $\begin{array}{l}\text { Indian Heart Journal/ Cardiological } \\
\text { Society of India }\end{array}$ & 1 & 2001 & Yes & $\begin{array}{l}\text { http://indianheartjournal.com } \\
\text { /index.htm }\end{array}$ \\
\hline $\begin{array}{l}\text { VetScan/Society For Advancement of } \\
\text { Veterinary Education }\end{array}$ & 1 & 2006 & No Print & http://www.vetscan.co.in/ \\
\hline Money \& Finance/ Icra Limited & 1 & 1997 & Yes & http://www.icraratings.com/ \\
\hline Medico-Legal Update/ Dr. R.K. Sharma & 1 & 2004 & Yes & $\begin{array}{l}\text { http://www.medicolegalupdat } \\
\text { e.org/ }\end{array}$ \\
\hline $\begin{array}{l}\text { Indian Journal of Forensic Medicine \& } \\
\text { Toxicoloy/ Dr. R.K. Sharma }\end{array}$ & 1 & 2007 & Yes & http://www.ijfmt.com/ \\
\hline $\begin{array}{l}\text { Indian Journal of Physiotherapy \& } \\
\text { Occupational Therapy/ Dr. Archna } \\
\text { Sharma }\end{array}$ & 1 & 2007 & Yes & $\begin{array}{l}\text { http://www.ijpot.com/htmlpa } \\
\text { ges/ }\end{array}$ \\
\hline $\begin{array}{l}\text { Journal of the Indian Institute of } \\
\text { Science/ Indian Institute of Science }\end{array}$ & 1 & 2001 & Yes & $\begin{array}{l}\text { http://journal.library.iisc.erne } \\
\text { t.in/index.html }\end{array}$ \\
\hline $\begin{array}{l}\text { Journal of Anatomical Society of India/ } \\
\text { Govt. Medical College, Patiala }\end{array}$ & 1 & - & Yes & http://jasi.net \\
\hline $\begin{array}{l}\text { Bioinformation/ Biomedical Informatics } \\
\text { Publishing Group }\end{array}$ & 1 & 2005 & Yes & $\begin{array}{l}\text { http://www.bioinformation.n } \\
\text { et/journal/about.htm }\end{array}$ \\
\hline $\begin{array}{l}\text { Siddha Papers/ Bethesda CAM Research } \\
\text { Center }\end{array}$ & 1 & 2007 & No print & $\begin{array}{l}\text { http://www.siddhapapers.org/ } \\
\text { Index.html }\end{array}$ \\
\hline Total & 178 & & & \\
\hline
\end{tabular}

\subsection{Subject Coverage}

Looking at the subjects covered by all 178 journals, they were broadly classified into two subjects i.e. Social Sciences and Science \& Technology. There were 17 journals deal with Social Sciences, which includes economics, law, Library and Information Science etc. Rest of the 161 journals were dominated by Science and Technology related subjects including Biomedical Sciences, Mathematics, Physical Sciences, Ayurveda etc. 


\subsection{Open access Journal Publisher / Host Organization}

It was observed that most of the journals are published or funded by government agencies such as ICAR, ICMR; academies such as IASc, INSA; learned societies; associations, commercial publishers and even editors. About 113 journals are published or hosted on behalf of journal such as Medknow and Indian Medlars Center, 24 journals are published by government agencies and academies, 5 journals from Learned societies, 4 journals by Associations, 10 journals by commercial publishers, 1 journal by hospitals, 8 journals by editors and rest i.e. 13 are published by research organizations, forums, Public Limited Company, Non profit organisations etc. The data is presented in Table No. 2.

Table No. 2: Open Access Journal Publisher / Host Organization

\begin{tabular}{|l|l|}
\hline Type & Number \\
\hline Hosted on behalf of journal & 113 \\
\hline Government agencies and academies & 24 \\
\hline $\begin{array}{l}\text { Research organizations, forums, Public } \\
\text { Limited Company, Non profit } \\
\text { organisations etc. }\end{array}$ & 13 \\
\hline Commercial publishers & 10 \\
\hline Editors & 8 \\
\hline Learned societies & 5 \\
\hline Associations & 4 \\
\hline Hospitals & 1 \\
\hline Total & 178 \\
\hline
\end{tabular}

\subsection{Indexing and Abstracting}

All journals were peer reviewed, indexed and abstracted in premier indexing and abstracting services such as Index Medicus, Chemical Abstracts Service, SCIRUS, SCOPUS, EMBASE etc. most of them are also linked from DOAJ, PubMed and OJ Gate. 
But the concept of Metadata harvesting and journal indexing services is still not familiar to the Open access journal publishers. Most of the Publishers simply upload the new issues of journals in their respective websites. This creates another major problem for the metadata harvesters and search engines. National Centre for Science Information (NCSI) at IISc, Bangalore has initiated a project called "Scientific Journal Publishing in India", sponsored by Asian Media Information and Communication Centre, Singapore (a division of IDRC, Canada). Through this project, NCSI campaigns to the open access journal publishers of India for early adaptation OAI-compliant architecture using Open Journal System (OJS) or similar software. (Ghosh, and Das, 2006)

\subsection{Full text availability}

Online full text availability of all 178 journals varies which has been presented in Table No. 1. In general their archives were mostly available from 1998 onwards. One of the oldest archive available online was the Journal of genetics published by Indian Academy of Sciences that dates back to 1910. Another journal, Journal of Pharmacology hosted by MedKnow Publication provides archive from 1969 onwards.

\subsection{Online/Print format}

Out of 178 Open access journals 15 journals were exclusively available only in online format i.e. they were not produced in print format or any other format. Rest 163 journals were available in print as well as online format. They are called Duel mode journal/Hybrid journals - print plus electronic, with the print version sold against a subscription. The open access journals are free to access but not free to produce. OA publishers need money to cover the cost of publishing. According to Sahu (2006) the cost for publishing is shared by subscriptions to the print journals, advertisements in print and online media, association membership fee, author reprints and grants from the government.

The journal titled 'Anil Aggrawal's Internet Journal of Forensic Medicine and Toxicology' was available online and CD format. Another journal named 'Journal of 
Association of Physicians of India' was available in print, CD and online format. All 151 Open access journals were freely accessible online but print and CD were distributed on subscription by the publishers except one journal titled 'Indian Folklife' published by National Folklore Support Centre distributes free print copies.

\subsection{Article Charges}

Even though all 178 journals provides open access or free access to reader but there were three journals where submission of articles to the journal was not free. They were author payable journals: Carbon - Science and Technology, International Journal of Human Genetics and Bioinformation

Carbon - Science and Technology published by Applied Science Innovations P Ltd asks authors nominal Obligatory Article Charge of Indian Rupees 9000 only (Approximately US \$250), towards partial support of the publication of the article and production and maintenance of the database, which the authors must pay. Also supplementary Information can be published online and has a deposit fee of Indian Rupees 1500 only (for up to $10 \mathrm{MB}$ of disc space). Supplementary Information can contain multimedia files, pdf files, word files etc. Authors from under-developed and developing countries can make a formal request for Article Charge Wavier. In such cases, quality of the articles is the sole criteria for such decisions.

International Journal of Human Genetics published by Kamla-Raj Enterprises, asks authors to pay for processing fee of the paper and photograph (if any in the paper) because the journal is available in print format as well. The corresponding author or first author gets a free print copy, but the other contributor/s need to buy a print copy. It is interesting to note that six other journals are published by Kamla-Raj Enterprises but do not ask authors to pay for article submission.

Bioinformation published by Biomedical Informatics Publishing Group ask authors processing fees under various categories mentioned in Table No. 2. General category is 
compulsory for all authors but it can be waived for needy authors after receiving acceptable justification. Other categories are optional. The data is presented in Table No. 3.

Table No 3: Categories of Fees

\begin{tabular}{|l|l|l|}
\hline Category & Charge & Description \\
\hline General category & $\begin{array}{l}\text { processing charge of } \\
\text { US\$100 }\end{array}$ & $\begin{array}{l}\text { Maintain a fast review } \\
\text { process of 3-4 weeks and } \\
\text { the article }\end{array}$ \\
\hline Express category & $\begin{array}{l}\text { additional processing } \\
\text { charge of US\$ 100 } \\
\text { will be completed and a } \\
\text { decision made within 1 } \\
\text { week }\end{array}$ \\
\hline Formatting service & $\begin{array}{l}\text { additional charge of US\$ } \\
100\end{array}$ & $\begin{array}{l}\text { Formatting done as per the } \\
\text { guidelines set by } \\
\text { BIOINFORMATION }\end{array}$ \\
\hline $\begin{array}{l}\text { Production of high } \\
\text { resolution illustrations }\end{array}$ & $\begin{array}{l}\text { additional charge of US\$ } \\
100\end{array}$ & $\begin{array}{l}\text { Production of a high } \\
\text { resolution illustration per } \\
\text { manuscript }\end{array}$ \\
\hline
\end{tabular}

\section{CONCLUSION}

With the number 178 (almost $21 \%$ of DOAJ journals) it can be said that India has made important contributions towards the growth of Open access publishing. Not only governmental funding agencies but also learned societies, associations and publishers have taken a step towards Open Access Movement in a right direction.

Also there are efforts been done through Open Access advocacy programmes conducted by NCSI, IISc, Indian Medlars, MedKnow etc. to create awareness among the scholarly community. This is making many Indian journals to become OA journals causing maximum access, visibility and impact to the research done in India. This is again evident from study done by Sahu (2006) that nine journals which are providing free access for last 3 years have reported no loss of subscriptions to the print version and in fact, have gained from the increasing subscriptions. Many journals which were running into losses 
are now self-sufficient to run the shown. It could be concluded that open access helps to improve the accessibility of the journals.

Even though overall picture of open access publishing in India looks promising, it makes unhappy situation from journal as well as publishing front. Minj, Singhal,\& Abraham (n.d.) found that most of these online Indian open access journals do not comply with indexing standards of OA, i.e. the OAI-PMH (Open Access Initiative - Protocol for Metadata Harvesting) protocol and thus lie outside the OAI interoperability framework. The search and display interface of these journals revealed lack of support for field-based metadata search and display. A consequence of this is that in spite of their online presence, the articles in these journals tend to be less used, as they are not easily 'discoverable' due to poor metadata and poor indexing.

In India, there are more than 300 universities and institutions of higher learning and hundreds of research laboratories, both in the government sector and in the private sector, but there are only 178 open access journals and 33 registered archives. The situation can turn dramatically, if national donor agencies such as the Department of Science and Technology and the Department of Biotechnology, and heads of major research councils such as the CSIR, UGC decide that the results of all publicly funded research should be made available through self archiving and encourage open access journal publishing initiatives.

\section{REFERENCES}

Ghosh, S. B. \& Das, A. (2006), “Open access and institutional repositories - a developing country perspective: a case study of India", World Library and Information Congress:

72nd IFLA General Conference and Council. Libraries: Dynamic Engines for the Knowledge and Information Society, Seoul, Korea, available at http://eprints.rclis.org/archive/00006391/01/157-Ghosh_Das-en.pdf (accessed 10 November 2007). 
Minj, S., Singhal, M., \& Abraham, T. n.d. "Barriers to electronic publishing of scholarly journals from India: Findings from the Scientific Journal Publishing in India (SJPI) Project", available at:

http://eprints.rclis.org/archive/00014861/01/India_paper.pdf (accessed 10 November 2007).

Sahu, D. K. \& Parmar, R. (2006), “The position around the world: Open Access in India", in Jacobs, N. (Ed.), Open Access: Key Strategic, Technical and Economic Aspects, Chandos Publishing, Oxford, pp. 26-32.

Sahu, D. K. (2006), “Open access publishing in the developing world: economics and impact”. In: Asia Commons: Asian Conference on the Digital Commons, 6-8 June 2006, Bangkok, Thailand, available at:

http://openmed.nic.in/1598/01/Openaccess_Medknow.pdf (accessed 10 November 2007).

The present preprint has been published in the journal Collection building. The details are as follows:

Sarika Sawant, (2009) "The current scenario of open access journal initiatives in India", Collection Building, Vol. 28 Iss: 4, pp.159 - 163 (DOI: 10.1108/01604950910999819) 